Clément P., 2013a - Muslim teachers' conceptions of evolution in several countries. Public Understanding of Science ('The public understanding of evolution in the Muslim World')- Published online before print August 13, 2013, doi: 10.1177/0963662513494549

\title{
Muslim teachers' conceptions of evolution in several countries
}

\author{
Pierre Clément
}

EA S2HEP, Université de Lyon, France

\begin{abstract}
Using a questionnaire validated by the project Biohead-Citizen, where 15 questions are dedicated to evolution, we analyze Muslim teachers' conceptions of evolution in several countries. The first part compares nine francophone countries, with varying degrees of Muslim or Christian culture: France, Morocco, Algeria, Tunisia, Lebanon, Senegal, BurkinaFaso, Cameroon and Gabon, and shows a strong contrast between France and the eight other countries. The second part compares Muslim and Christian teachers in the countries where the comparison is possible, finding no difference, or a few differences in Lebanon. The third part analyzes the data related to the 2130 Muslim teachers sampled to identify the controlled parameters that can be correlated to their variations. The discussion is structured by three questions: Are Muslim countries, and Muslim teachers, more creationist than other ones? Is the teachers' knowledge related to their more or less creationist conceptions? Are Muslim teachers more creationist in European countries?
\end{abstract}

\section{Keywords}

Arabic countries; biology/evolution; creationism; gender and science; Muslim religion; science and religion; science in schools; social representations; sub-Saharan countries; teachers

\section{Corresponding author:}

Pierre Clément, S2HEP Sciences, Société : Historicité, Education et Pratiques - EA 4148, Université Lyon 1, La Pagode, 38 bd Niels Bohr, 69622 Villeurbanne, France.

Email: Pierre.Clement@univ-lyon1.fr 


\section{Introduction}

The present work deals with conceptions of evolution amongst Muslim teachers. The choice of teachers has two main justifications. They are key-persons in education; and they are amenable to comparative research at an international level. Do their conceptions differ amongst countries? Do they differ from those of their Christian colleagues in the countries where this comparison is possible? Are they differing with other parameters than countries?

On 21 June 2006, the InterAcademy Panel (IAP), representing 68 national science academies, published a joint statement on the teaching of evolution: "We, the undersigned Academies of Sciences, have learned that in various parts of the world, within science courses taught in certain public systems of education, scientific evidence, data, and testable theories about the origins and evolution of life on Earth are being concealed, denied, or confused with theories not testable by science" (IAP, 2006). These problems were mainly analyzed in U.S., since the Little Rock Process in December 1981 (Gould, 1983, Lecourt, 1992). The debates were then extended in Europe (Graebsch \& Schiermeier, 2006; Baudouin \& Brosseau, 2008). Creationist ideas, relayed by intelligent design, were mainly defended by fundamentalist Protestants, but appeared more recently as also defended by fundamentalist Muslims (Keskas, 1994; and mainly the books of Harun Yahya with the large and free diffusion of the tome 1 of his Atlas of Creation). Several books and articles analyzed the place of science and religion when teaching evolution (for instance Jones \& Reiss, 2007; Coquidé \& Tirard, 2008 ; Portier, Veuille \& Willaime, 2011), but with papers mainly focused each one on only one country. Moreover, few of these works dealt with teachers' difficulties, with some exceptions, as in Great Britain (Reiss, 2008), in Brazil (El-Hani \& Sepulveda, 2010) or in Lebanon (BouJaoude et al., 2009).

Until now, few studies have analyzed the perception of evolution in Muslim countries. The international synthesis published by Miller, Scott \& Okamoto (2006) compared the public acceptance of evolution in 34 countries where only one (Turkey) was Muslim: about $25 \%$ of adults in Turkey agreed with the proposition "Human beings, as we know them, developed from earlier species of animals": less than in U.S. (about 40\%) and even less than in the 32 other countries.

Using a sociological study (Hassan, 2007) which included only one question related to evolution ("Do you agree or disagree with Darwin's theory of evolution?"), Hameed (2008) published that $22 \%$ of Turks, $16 \%$ of Indonesians, $14 \%$ of Pakistanis, $11 \%$ of Malaysians and $8 \%$ of Egyptians agree, while $40 \%$ in Kazakhstan. The diversity of Muslims' conceptions of evolution needs a larger research, in more countries, using more than only one question, and comparing the same sampling in each country.

I regularly taught in the universities of Tunis (Tunisia), Algiers, Tlemcen (Algeria), Marrakech (Morocco), Dakar (Senegal) and Beirut (Lebanon). I also visited schools in Sarajevo (Bosnia) and Ouagadougou (Burkina Faso), The diversity of the Muslim world is complex, comprising historical and geographical dimensions, but also, within each country, with several trends, some of them being more fundamentalist. Not all these trends are antievolutionist.

A long time before Darwin, some Muslim intellectuals already considered that there is a continuity between minerals and living beings, with the successive emergence of plants, then animals and then human beings and angels: Ikhwan as-Safa ( $10^{\text {th }}$ Century), Al-Qazwini (1203 - 1283) (Mazhar, 1917), and the great historian from the Maghreb, Ibn Khaldun (1332 1406) in his famous "Al muqaddima" (Djebbar, 2001). 
After Darwin, several Arabic scientists defended evolution. Some were Christian from Lebanon or Egypt. For instance the Lebanese Schumayyil (1850-1917) was more materialist while others tried to reconcile faith in God with science (Haroun, 1985): Mazhar (1917), an Egyptian writer, translated in Arabic and then disseminated "The origin of species" of Darwin as a scientific book; Moussa (1925), Coptic Egyptian, explained that "Darwin did not say that humankind descends from apes, but that both have the same origin". There were also Muslim Arabic intellectuals who defended evolutionism, trying to reconcile it with creationism, in a kind of compromise proposed by Hussein in 1924 (Iqbal, 2009; Yassin \& Bastide, 2011). An earlier example is El Gissr who wrote in 1887 that Islam can admit the theory of evolution if finally all these processes are attributed to God, "motor of evolution and of its laws". For him, evolution was still an hypothesis, while, today, it is more than that.

At the end of his famous paper "Nothing in biology makes sense except in the light of evolution", Dobzhansky (1973) quoted this claim of Teilhard de Chardin: "evolution is a light which illuminates all facts, a trajectory which all lines of thought must follow". Teilhard de Chardin was also a Catholic priest, and the successive phases of his view of evolution (Teilhard de Chardin, 1957) are a kind of scientific evolutionist actualization of the successive steps proposed by some Muslim intellectuals before Darwin, except for the final step where "angels" are replaced by the "noosphere" and finally the "Omega point".

This reconciliation between evolutionist conceptions and faith in God is even more clearly expressed by Dobzhansky in the same famous paper (1973, p.127): "I am a creationist and an evolutionist. Evolution is God's, or Nature's, method of Creation." This position is very important in the research presented below.

Introducing the Conference "Darwin and Evolution in the Muslim World" in Hampshire College (2009), Hameed pointed the absence of data in Sub-Saharan Africa, as well as in North Africa. The present work in mainly focused on eight of these countries (Africa + Lebanon), all of them being inside the Francophone area, and not yet involved in the international surveys related to the acceptance of evolution. Hameed also said: "We actually expect, especially in Europe, where they have a harder time merging in the culture, harsher rejection of evolution in England and Germany than in Muslim countries" (Chang 2009). To take into account this hypothesis, I also analyze below the conceptions of the few Muslim teachers included in our sampling of European countries, in France and Scandinavia.

Our research on teachers' conceptions of evolution in several countries was linked with the analysis of the place of evolution in syllabuses and textbooks in the same countries. Our results of these both approaches were partly published, mainly in Conferences Proceedings or Books (Author, or Author et al., 2008, 2009, 2012), but also in Journals (Author et al, 2008, 2009, 2011, 2012) as well as in a PhD thesis (Quessada, 2008). Nevertheless, the present paper is the only one focused on the conceptions of Muslim teachers. The Christian teachers' conceptions of evolution were analyzed amongst 16 countries in another paper (Author 2012). Other authors have analysed the conceptions and difficulties of learning evolution for students in a Muslim country, for instance in Tunisia (Aroua, 2006, 2008, Aroua et al., 2007, 2009; Kebaïli, 2012) or in Lebanon (Dagher \& BouJaoude, 2005 ; Hokayem \& BouJaoude, 2008), or described the place of evolution in the Egyptian syllabus (Yassin \& Bastide, 2011). From these works, the Muslim religion taught in regular schools (as well as in Koranic Schools where they exist) seems to have more influence on pupils and then students than the scientific approach of evolution introduced only at the end of the secondary school. 
To identify the teachers' conceptions of evolution, using a questionnaire for international comparisons, a researcher must propose several questions to be able to analyze the conceptions underlying all the answers through different situations. When the conceptions are shared by a social group, we can use the terminology "social representations" (Moscovici, 1984). When different conceptions or social representations are correlated, they correspond to a "system of conceptions" (Author 2010).

Another theoretical background used here is the KVP model (Author, 2004, 2006, 2010), proposing to analyze conceptions as possible interactions of three poles: scientific knowledge $(\mathrm{K})$, values $(\mathrm{V})$ and social practices $(\mathrm{P})$.

In the present work, some questions of our questionnaire deal mainly with the scientific knowledge of teachers, while others mainly deal with their values. We call values that which is the basis of a judgement (Author, 2010, 2012): what is truth or not, what is good or not, ... Some of these values found what is scientific or not, others found a belief or an ideology. Most of them are linked to individual and social practices.

Our main question of research here is to identify if the conceptions of Muslim teachers related to evolution (and/or creation) are correlated to their religion, or if they are also, and possibly more, correlated to the socio-cultural and economical context of their country (parts I and II of the following results). I shall then analyze if they are also correlated to other controlled parameters (part III of results).

\section{Methodology}

\section{Sampling}

To allow international comparison, we applied the same questionnaire to an identical and balanced sample in each country, of in-service teachers (In) and pre-service teachers (Pre), practicing at Primary schools (P), or teaching Biology (B) or national Language (L) at secondary school; and this yielded six sampling groups (InP, PreP, InB, PreB, InL, PreL) with generally 50 teachers per group (about 300 in each country). We controlled the sampling to be balanced within each country, while by country the number of individuals could vary, to allow more detailed analyses in some countries (e. g, in Lebanon to compare the different Muslim or Christian confessions).

A large part of the results presented here come from the data collected during the BioheadCitizen project: Biology, Health and Environmental Education for better Citizenship: (European project FP6 CIT2-CT-2004-506015): data from five Muslim countries: Morocco, Algeria, Tunisia, Senegal and Lebanon, as well as from France and Estonia. The other data were collected afterwards, under my direct responsibility, to enlarge our sampling in Africa (Burkina Faso, Cameroon, Gabon) as well as in other European countries with few Muslim teachers (Denmark, Sweden). The total sampling used in the present work is presented in the table 1. All the countries of our sampling are inserted in the international French-speaking community, except the three Nordic European countries (Sweden, Denmark and Estonia) where there are few Muslim teachers, who are grouped in the category Muslim Scandinavian teachers, which is only used in the analyses of the part III of our results.

Part I of our results compares the teachers' conceptions in the 9 Francophone countries.

Part II deals only with analyses country by country, where the comparison between Muslim teachers and their colleagues is possible. For instance, it is not possible in Morocco or Algeria where almost all the teachers are Muslim.

Part III is restricted to the Muslim teachers from all the countries listed in the Table 1. 
Table 1. Samples and religion of the interviewed teachers. Agn $=$ Agnostic or Atheist, Catho $=$ Catholic, Prot $=$ Protestant, Orth $=$ Orthodox, Other $=$ Other religions, $N R=$ No answer to this question.

$\mathrm{N}$ Muslim $=$ Number of Muslim teachers.

\begin{tabular}{|c|c|c|c|c|c|c|c|c|c|c|c|c|}
\hline & Country & $\begin{array}{l}\text { To- } \\
\text { tal }\end{array}$ & $\begin{array}{c}\text { Inclu- } \\
\text { ding } \\
\text { Bio }\end{array}$ & $\begin{array}{c}\% \\
\text { Agn }\end{array}$ & $\begin{array}{c}\% \\
\text { Catho }\end{array}$ & $\begin{array}{c}\% \\
\text { Prot. }\end{array}$ & $\begin{array}{c}\% \\
\text { Orth }\end{array}$ & $\begin{array}{c}\% \\
\text { Muslim }\end{array}$ & $\begin{array}{c}\mathbf{N} \\
\text { Muslim }\end{array}$ & $\begin{array}{c}\% \\
\text { Other }\end{array}$ & $\begin{array}{c}\% \\
N R\end{array}$ & $\begin{array}{c}\text { Sections } \\
\text { of } \\
\text { Results }\end{array}$ \\
\hline DZ & Algeria & 223 & 88 & 1,3 & 0,0 & 0,0 & 0,0 & 91,9 & 205 & 0,0 & 6,7 & I, III \\
\hline MA & Morocco & 330 & 186 & 0,6 & 0,0 & 0,0 & 0,0 & 97,3 & 321 & 0,3 & 1,8 & I, III \\
\hline SN & Senegal & 324 & 120 & 0,9 & 8,3 & 0,0 & 0,0 & 89,2 & 289 & 0,0 & 1,5 & I, II, III \\
\hline TN & Tunisia & 753 & 326 & 1,9 & 0,0 & 0,0 & 0,0 & 96,0 & 723 & 0,3 & 1,9 & I, II, III \\
\hline $\mathbf{B F}$ & Burkina & 296 & 110 & 2,4 & 45,6 & 18,6 & 0,0 & 24,7 & 73 & 1,7 & 7,1 & I, II, III \\
\hline LB & Lebanon & 722 & 261 & 0,4 & 21,1 & 0,4 & 8,3 & 65,0 & 469 & 0,3 & 4,6 & I, II, III \\
\hline DK & Denmark & 259 & 111 & 44,8 & 1,9 & 34,4 & 0,0 & 3,5 & \multirow{3}{*}{$\begin{array}{c}9+3+1 \\
=13 \\
\end{array}$} & 5,0 & 10,4 & \multirow{3}{*}{ III } \\
\hline SE & Sweden & 377 & 147 & 37,1 & 1,6 & 38,7 & 2,9 & 0,8 & & 7,2 & 11,7 & \\
\hline EE & Estonia & 182 & 108 & 43,4 & 7,7 & 14,8 & 2,2 & 0,5 & & 8,2 & 23,1 & \\
\hline FR & France & 732 & 319 & 50,5 & 38,1 & 1,9 & 0,3 & 1,5 & 11 & 2,7 & 4,9 & I, II, III \\
\hline GA & Gabon & 269 & 87 & 0,4 & 48,0 & 29,7 & 1,5 & 3,0 & 8 & 14,5 & 3,0 & I, III \\
\hline CM & Cameroon & 523 & 267 & 7,5 & 47,0 & 28,9 & 0,2 & 3,4 & 18 & 8,2 & 4,8 & I, II, III \\
\hline
\end{tabular}

In the countries listed in the table 1, it is possible to compare the Muslim teachers' conceptions to those of other teachers only in some countries (section II of results, indicated in the column at right). All the countries are involved in the analyses of the sections I and III of the results, except "Scandinavia" (Denmark + Sweden + Estonia), only involved in the section III.

\section{Questionnaire}

We took two full years to collectively design the BIOHEAD-Citizen questionnaire (Author et al, 2007). Starting with a bibliography to select some questions already validated, we added others related to our hypotheses, using interviews and then a long pilot test. This pilot test was translated into each national language using several complementary processes: parallel independent translations, from which was built a consensual translation, this then being retrotranslated and compared with the initial formulation (the reference questionnaire was in English). In several countries, the questionnaire was filled out twice by 30 to 100 pre-service teachers (depending on the country), with one month of delay, to analyze the reliability of their answers: when answers were not reliable, the question was eliminated. In a second step, we used the long pilot questionnaire with at least 50 pre-service teachers, in most countries; their answers were then analyzed, and only the questions differentiating the teachers' answers were utilized in the final questionnaire. The ranking of questions was determined at random, and the same final questionnaire was then used in all the countries. The results presented below come from this last step using the final questionnaire.

In the present work, we only use two sets of questions:

(1) Information on demographics (age, gender, etc) and socio-cultural background, including 13 questions related to political or religious opinions.

(2) 15 questions related to evolution, that can be grouped into three categories:

- Opinion about creation and / or evolution: A64, B28, B48, A62, B29a, B29b

- Opinion related to a goal-directed evolution: A33 and A44.

- Knowledge related to the importance of some processes of evolution (B42, B43, B44, $\mathrm{B} 45, \mathrm{~B} 46, \mathrm{~B} 47)$ or to the possibility of including Chimpanzees in the genus Homo (B7). 
These questions are listed below, in the order they appear into the questionnaire:

A33. The emergence of the human species (Homo sapiens) was just as improbable as the emergence of any other species.

A44 The emergence of the human species (Homo sapiens) was the aim of the evolution of living species

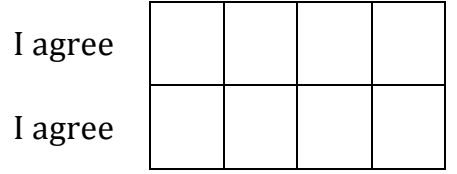

I don't agree I don't agree

A62. In the list below, tick the THREE expressions that you think are the most strongly associated with the origins of humankind.

$\square$ Adam and Eve $\quad \square$ Australopithecus $\quad \square$ Creation $\quad \square$ Evolution $\quad \square$ God $\quad \square$ Natural selection

A64. Which of the following four statements do you agree with the most? (tick only ONE answer)

$\square$ It is certain that the origin of life resulted from natural phenomena.

$\square$ The origin of life may be explained by natural phenomena without considering the hypothesis that God created life.

$\square$ The origin of life may be explained by natural phenomena that are governed by God.

$\square$ It is certain that God created life

B7 The Chimpanzee should be included in the genus Homo, notably because $98.5 \%$ of its DNA is identical to that of Homo sapiens.

I agree

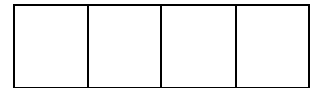

I don't agree

B28. Which of the following four statements do you agree with most? Select ONLY one sentence:

$\square$ It is certain that the origin of the humankind results from evolutionary processes.

$\square$ Human origin can be explained by evolutionary processes without considering the hypothesis that God created humankind.

$\square$ Human origin can be explained by evolutionary processes that are governed by God.

$\square$ It is certain that God created humankind.

B29. Tick "Yes" or "No" for each sentence:

B29a - The theory of evolution contradicts my own beliefs $\quad \square$ Yes $\quad \square$ No

B29b - Creationism (including the creation of human beings by God) contradicts my own beliefs

$\square$ Yes $\square$ No

Indicate your evaluation of the importance of the following factors in species evolution (tick only $\underline{\mathrm{ONE}}$ box for each line):

\begin{tabular}{|l|l|l|l|l|l|}
\cline { 2 - 5 } \multicolumn{2}{c|}{} & $\begin{array}{c}\text { Great } \\
\text { importance }\end{array}$ & $\begin{array}{c}\text { Some } \\
\text { importance }\end{array}$ & $\begin{array}{c}\text { Little } \\
\text { importance }\end{array}$ & $\begin{array}{c}\text { No importance } \\
\text { at all }\end{array}$ \\
\hline B42. & Chance & & & & \\
\hline B43. & Natural selection & & & & \\
\hline B44. & $\begin{array}{l}\text { A program inside the } \\
\text { organism (intelligent design) }\end{array}$ & & & & \\
\hline B45. & Surrounding environment & & & & \\
\hline B46. & Transposons (jumping genes) & & & & \\
\hline B47. & Viruses & & & & \\
\hline B48. & God & & & & \\
\hline
\end{tabular}

Procedure and data analysis 
In each participating country, teachers filled out the questionnaire anonymously in a dedicated room within their school or after a teaching sequence at the University, in the presence of researcher who collected the filled questionnaire immediately.

Each national team filled an Excel file, transmitted it to me for the statistical analyses, then done with the help of statisticians. When more than $5 \%$ of questions are without answer, the questionnaire is withdrawn.

Beside classical statistical tests (as Chi2), other computations were performed using the statistical software R (Ihaka \& Gentleman, 1996) with the multivariate analysis package ade4. For the present work, we used different methods:

- Between-class analyses (Dolédec and Chessel, 1989) to discriminate between groups of individuals (e.g. different countries, biology teachers and non-biology teachers, gender, etc.) in order to analyze which conceptions differentiate the most between these groups. A Monte-Carlo permutation test (Romesburg, 1985) implemented in the ade4 libraries was then used to see if the difference between groups is or is not significant.

- Sometimes, differences between groups can be a single consequence of another difference. Using the Principal Component Analysis of the Orthogonal Instrumental Variables (PCAOIV), we can suppress the effect of one variable (Sabatier et al., 1989) to see if the difference persists or not.

- The co-inertia analysis is used to compare two sets of questions: for instance the personal political and religious opinions with those related to evolution, and to see the possible correlations between them (Dray et al., 2003).

These kinds of statistical methods are often used in ecology (Dolédec \& Chessel, 1989), but they are also frequently used in sociology (Busca \& Toutain, 2009) and are suitable to analyse our data (Munoz et al., 2009).

\section{Results}

As mentioned above, all the countries of our sampling where most of the teachers are Muslim (Tunisia, Algeria, Morocco, Senegal, Lebanon: table 1) are inserted in the international French-speaking community. Our first analyses compare them to France and to other Francophone African countries where there are some Muslim teachers (Burkina Faso) or mainly Christian teachers (Cameroon and Gabon), to identify at what point the differences of teachers' conceptions of evolution are or not linked to the amount of Muslims in their country.

In a second set of results, the conceptions of evolution held by Muslim teachers are compared to those held by teachers of other religions inside the same country, to identify if beside the country effect shown in the first part of results, there is also a specific effect of religion.

In the third set of results, only the Muslim teachers' conceptions of evolution are analysed, to identify the controlled parameters that can be correlated to their variations.

\section{-I- Comparison of teachers' conceptions in nine French-speaking countries}

French is the official language in Senegal, Burkina-Faso, Gabon and, with English, in Cameroon, and is the main practiced language just after Arabic in Morocco, Algeria, Tunisia and Lebanon. Is the historical influence of France and French culture still present in these African or Middle-East countries when dealing with evolution? 
The syllabuses and school biology textbooks suggest important differences among these countries, already analyzed in previous works (e.g. Quessada et al., 2008). For instance, the topic Evolution is totally absent in Algeria, has been just recently re-introduced in Morocco, was reintroduced in 1998 in Lebanon but then again suppressed and more recently reintroduced. While in Tunisia it is present but only at the end of secondary schools and omitting the sensitive question of the origin of humankind.

What about the teachers' conceptions related to Evolution in these countries?

The Figure 1 shows a strong opposition between teachers' conceptions in France and in the other countries.

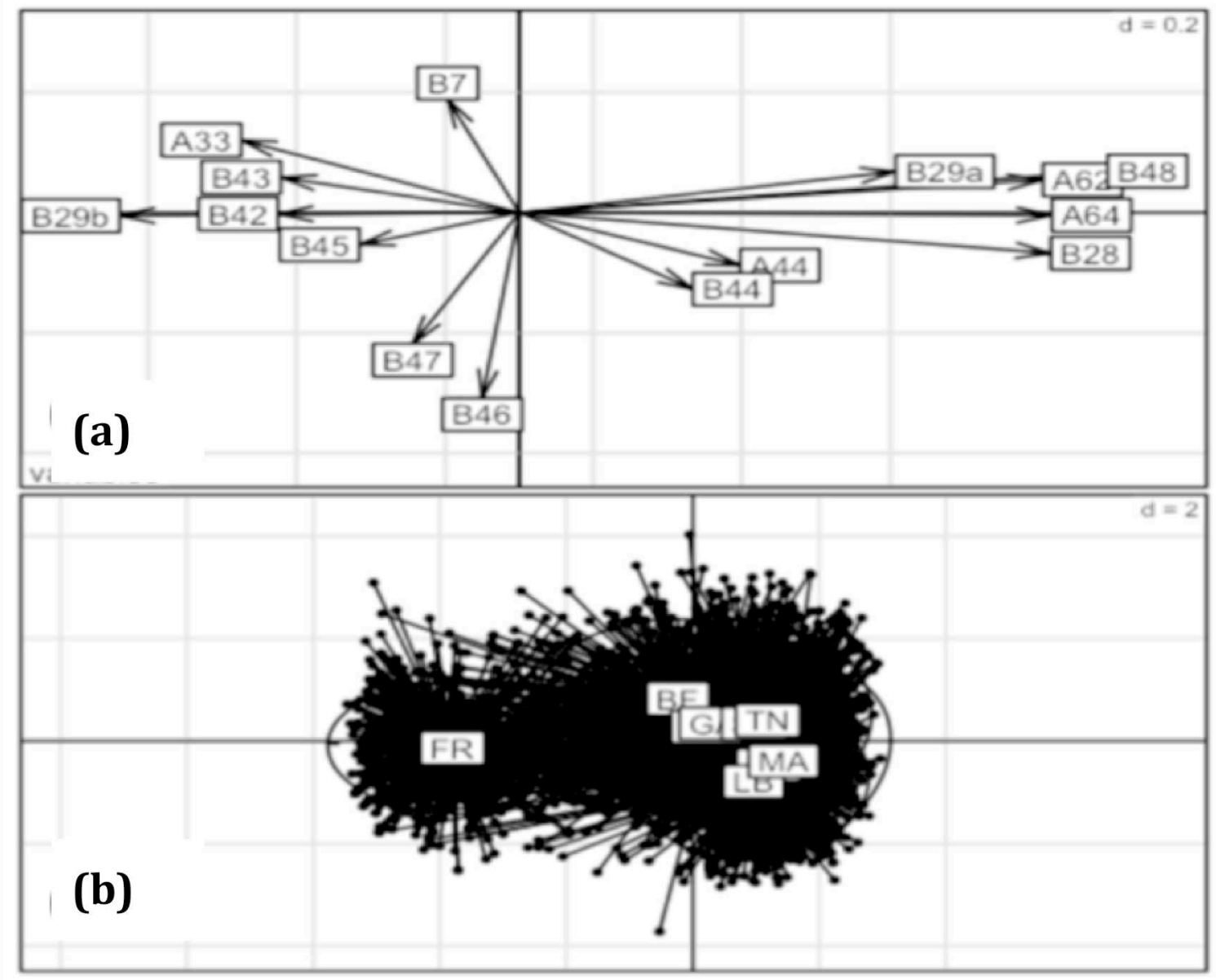

Figure 1. Between-class analysis differentiating between the nine countries.

(a) The variables differentiating the most among the countries correspond to the longest vectors: at right are the most creationist conceptions and at left the most evolutionist ones.

(b) Each point, corresponding to the conceptions of a teacher, is relied to the centre of gravity observed for each country: from left to right: $\mathrm{FR}=$ France; $\mathrm{BF}=$ Burkina Faso; $\mathrm{GA}=$ Gabon, hiding $\mathrm{CM}=$ Cameroon; $\mathrm{TN}=$ Tunisia, hiding $\mathrm{SN}=$ Senegal; MA = Morocco, just hiding DZ = Algeria, partly hiding LB = Lebanon.

The differences among the nine countries are highly significant $(\mathrm{p}<0.001$, from the randomisation test).

This differentiation is explained by the first component of the analysis, opposing French teachers' conceptions (at left in the Figure 1) to other conceptions (at right in the Figure 1). The conceptions of French teachers are much more evolutionist (Figure 1a: questions B48, B28, A64, A62, B29a and B29b), less agreeing a "goal-ended evolution" (A33 and A44), indicating importance of chance and of natural selection (questions B42 and B43) but not of 
intelligent design (question B44). Other questions related to scientific knowledge on evolution are not correlated with this first component (B46, B47, B7: vertical axis in Figures $1 \mathrm{a}$ and $1 \mathrm{~b}$ ), showing a limited KV (knowledge-values) interaction.

A first conclusion is the absence of large differences among the eight African and / or Arabic countries of our sample: whether in "Muslim countries" or "Christian countries", their teachers' conceptions are strongly opposed to the conceptions of the French teachers. This opposition is linked to the great difference of economic level between France and the other eight countries, as well as to the high number of Agnostic / Atheist teachers in France (table 1).

To analyze more deeply the possible differences among the nine countries, we can compare the teachers' answers to the most discriminating questions (B48, A64, B28: Figure 2).

Most of the interviewed teachers, except in France, answered that God has a great importance, or sometimes some importance, in the evolution of species (Figure 2-B48); but several of them are, as claimed by Dobzhansky in 1973, "at the same time evolutionist and creationist" (item 3: in white in the Figures 2-A64 \& 2-B28): for respectively the questions A64 and B28, from $35 \%$ \& $36 \%$ in Gabon, to $12 \%$ \& $6 \%$ in Algeria).

Another conclusion, comparing the Figures 2-A64 and 2-B28, is the great similarity of the teachers' answers to the questions B28 (origin of humankind) and A64 (origin of life). That contradicts our initial hypothesis, expecting more creationist answers when dealing with the origin of humankind, which is a sensitive question often omitted in syllabuses and textbooks in countries as Algeria, Morocco, Lebanon or even Tunisia (Quessada et al., 2008, Quessada, 2008). Our results clearly show that we were wrong in our initial hypothesis: the origin of life is as sensitive as the origin of humankind.

The third conclusion is the importance of differences among the nine countries. For each question related to evolution, we compared the answers coming from a country to the answers coming from each of the eight other countries (comparison by pairs of countries: Chi2 with the Bonferroni correction). For instance, from the answers to the question A64 (Figure $2-A 64)$, there are several very significant differences $(p<0.001)$ : France differs from all the other countries. Burkina Faso differ from countries other than Gabon and Cameroun, which are not different among themselves but differ from the other countries. The five Arabic countries (Algeria, Morocco, Tunisia, Senegal and Lebanon) do not differ among themselves but differ from the other countries.

The same differences emerge from the question B28 (Figure 2-B28), where nevertheless Burkina Faso differs from all the other eight countries, and Tunisia differs from countries other than Senegal, and less with Lebanon $(p=0.016)$.

In consequence, there is a clear effect of country, which cannot be reduced to an opposition between "Muslim countries" and other ones. For instance, in Lebanon and in Burkina Faso, there are Christian as well as Muslim teachers (table 1). To go further in the analyses, trying to separate the country effect from the religion effect, we must compare, inside the same country, the answers of teachers belonging to different religions. That is possible only in some of the countries of our sample (table 1). 

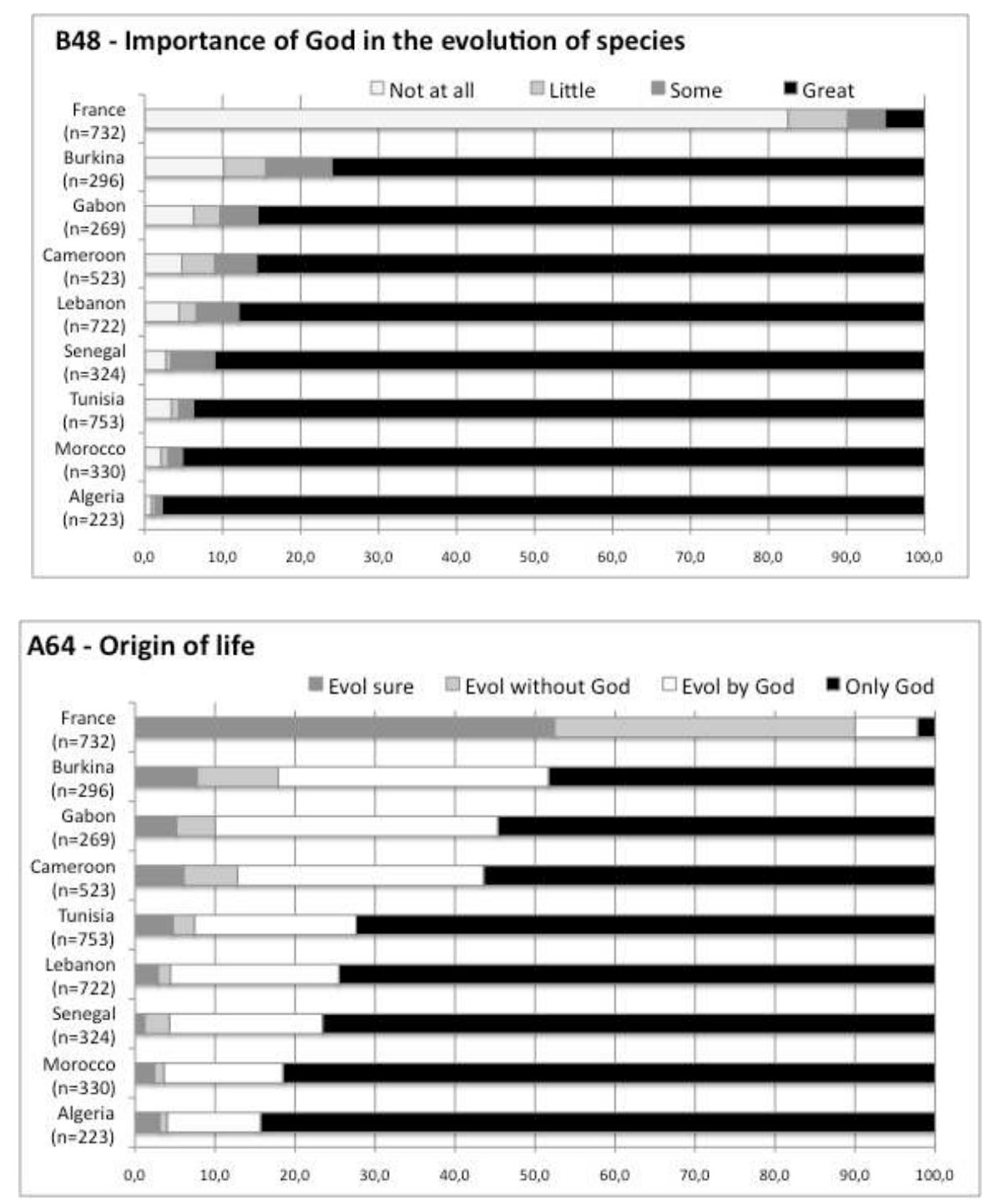

\section{B28 - Origin of humankind}

Evol sure $\square$ Evol without God $\square$ Evol by God $\mathbf{m}$ Only God

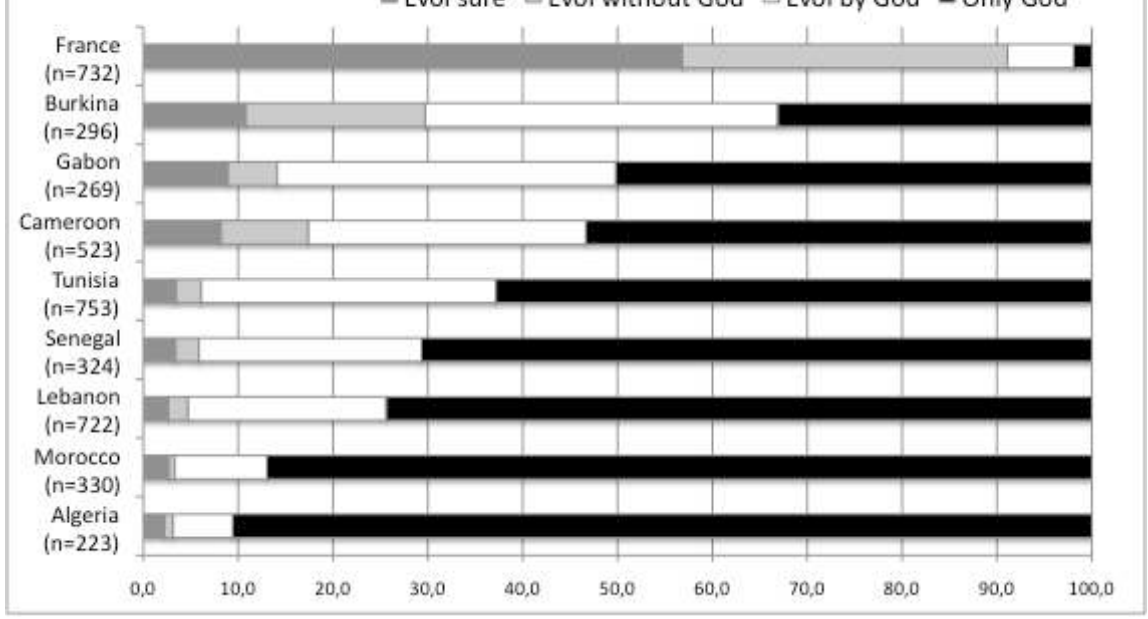

Figure 2. Teachers' answers (grouped by country) to the questions

- B48 (importance of God in the evolution of species): in white: no importance at all; in grey: little or some importance; in black: great importance.

- A64 (the origin of life) and B28, (the origin of humankind): in grey, evolutionist answers; in white: both evolutionist and creationist answers; in black: more radical creationist answers 


\section{-II- Comparison between Muslim and other teachers inside some countries.}

Burkina Faso. Making the comparison between the different religions, we do not consider the teachers ticking "Agnostic" or "Atheist" (7 teachers), nor "Else Christian" (2), nor "No answer" (21) nor "Other religion (3). We compare three groups: Catholic (135 teachers), Protestant (55 teachers) and Muslim teachers $(73=55$ Sunni +13 Shiites +5 Other Muslims).

The Chi2 (multiple comparison with adjustment method Bonferroni) shows no significant difference between Muslim and Catholic teachers' conceptions, but a difference between Muslim and Protestant ones $(\mathrm{p}=0.022)$ : in Burkina Faso, Muslim teachers are more evolutionist than their Protestant colleagues when answering to the question A64 (origin of life): Appendix A1.

For the answers to the question B28 (Appendix A2), there is no significant difference ( $\mathrm{p}$-value $=0.23$ ). We can conclude that, for the same socio-cultural and economical context (inside the same country: Burkina Faso), the Muslim teachers are not more creationist than the Christian ones. The relatively less creationist conceptions of teachers in Burkina Faso are not due to the amount of Christian teachers in this sample: it is a consequence of the national specificity of this country, that can be observed on both Muslim and Christian teachers.

Nevertheless, the difference between Protestant and Muslim teachers for the question A64 (origin of life) is interesting to comment, Protestant teachers being here more creationist than their Muslim colleagues. In European countries, where Protestants are Calvinist or Lutherian, we did not find any significant difference, inside each country, between Protestant and Catholic teachers (Author 2012). In Burkina Faso, most of the Protestant churches are also present in America (in USA as well as in South America) and are more fundamentalist concerning evolution. We showed that in Brazil (Author 2012), where this position of fundamentalist Protestants is deeply discussed by El Hani. \& Sepulveda (2010).

Cameroon. In Cameroon, we observe a clearer absence of difference than in Burkina Faso (Appendix A3). We compared four groups of teachers in this analysis: Agnostic or Atheist (39 teachers), Catholic (246), Protestant (151) and Muslim (18). The results show a great homogeneity of answers, whatever is the teacher's religion, illustrating here also that the country effect is more important than the initially suspected religion effect.

Senegal. In our sample (table 1), 27 teachers are Catholic and 289 are Muslim. A betweenclass analysis from the 15 questions dealing with evolution shows a clear absence of difference between the two groups (from the randomization test).

Lebanon. Lebanon is a more complex country, where religious confessions play a major political role. For this reason, we decided to have a more important sampling (total $\mathrm{N}=722$, table 1), in particular to compare the religions. We kept two groups of Christian teachers, Catholic ( $\mathrm{N}=152$, mainly Maronites but also Greek Catholics, etc.) and Orthodox $(\mathrm{N}=60)$; and three groups of Muslim teachers: Sunni $(\mathrm{N}=218)$, Shiites $(\mathrm{N}=184)$ and Druzes $(\mathrm{N}=66)$. We did not take into account small groups: Agnostic or Atheist $(\mathrm{N}=3)$, Protestant $(\mathrm{N}=3)$, Other Christian $(\mathrm{N}=2)$, Other Muslim $(\mathrm{N}=1)$ nor the absence of answer $(\mathrm{N}=33)$. 
The randomization test (Monte Carlo) associated to a between-class analysis discriminating these five groups shows very significant differences $(p<0.001)$, related to the degree of creationist/evolutionist conceptions (Figure 3). Sunni and Chi'ite teachers are more creationist than the Orthodox and Catholic teachers, but also more than their Druze colleagues.

The teachers' answers differentiating the most the five groups are related to creationism (B28, A64, B48, A62, B29a) but also with the knowledge of importance of natural selection in species evolution (B43). We analyze below these answers for three of these questions (A64, B28, B43: the corresponding Figures are in Appendix A4, A5 and A6).

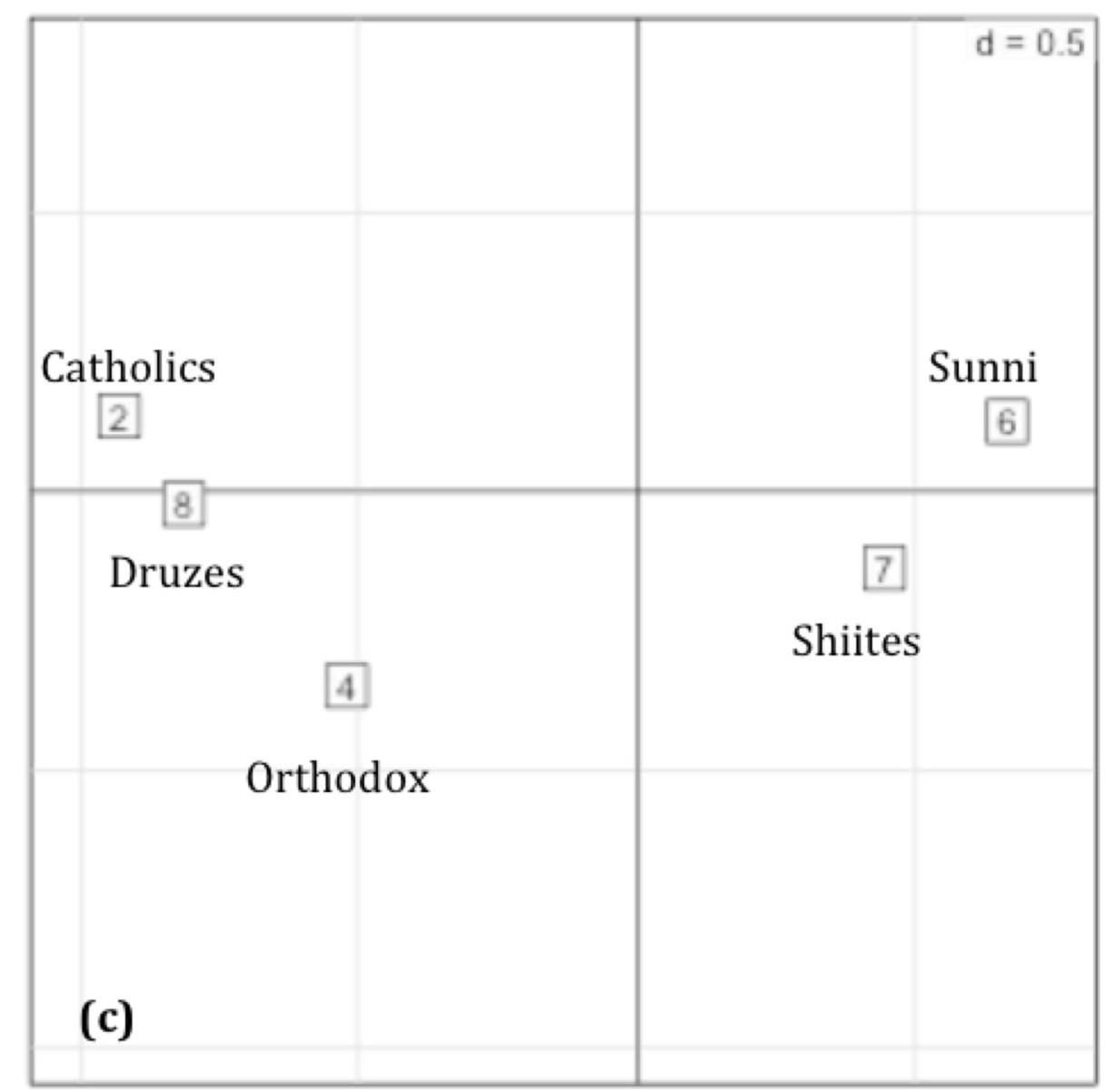

Figure 3. Lebanon: Between-class analysis differentiating the five groups of teachers, depending their religion. At right of the horizontal axis is the most creationist pole, at left the less creationist (more evolutionist) pole.

Analyzing the Lebanese teachers' answers to the question A64, the Pearson's Chi-squared test shows clear differences among the five groups ( $p$-value $<0.001$ ), while the comparisons of religions two by two (Chi2) show a significant difference only between Sunni and Catholics $(\mathrm{p}<0.001)$, Sunni and Druzes $(\mathrm{p}=0.01)$, Shiites and Catholics $(\mathrm{p}=0.0016)$. There is no significant difference between Druze and Shiites, Druze and Orthodox, Druze and Catholic ; nor between Shiites and Sunni, nor between Shiites and Orthodox. 
Similar comments are possible when analyzing the answers to the question B28. The Sunni and Shiites do not differ, and differ significantly from the Catholic and Orthodox teachers. There is no significant difference between Druze teachers and the four other groups.

The same trends can be observed in the answers to the question B43 related to the importance of natural selection in species evolution: Druze, Catholic and Orthodox teachers ticked "great or some importance" more than their Chi'ite and particularly Sunni colleagues. Nevertheless, it is interesting to remark that a majority of creationist teachers (when answering to the questions A64 and B28) recognize the importance of natural selection in species evolution when answering to the question A43.

Tunisia. In Tunisia, only 14 teachers claimed to be Agnostic or Atheist. When compared to the 723 Muslim teachers, their answers are very significantly different, the first ones being more evolutionist.

France. In France, a between-class analysis differentiates four groups of teachers (grouped by their religion: 370 Agnostic or Atheist, 279 Catholic, 11 Muslim and 14 Protestant). The difference is clearly significant (test of randomization). Nearly all agnostic or atheist teachers are clearly evolutionist (Appendix A8).

Concerning the 11 Muslim teachers, seven of them ticked great or some importance of God in species evolution (question B48, Appendix A7), while for the question B28 only three of them ticked the radical creationist item (Appendix A8).

In conclusion of this second part of results, in most of the analysed countries where a comparison was possible (Burkina Faso, Cameroon, Senegal, as well as in Gabon, not discussed above because there are less Muslim teachers), there is no difference between Muslim and Christian teachers when they are compared within the same country, whereas the difference between Muslim or Christian teachers compared to Agnostic /Atheist teachers is very significant in France and Tunisia, but not in Cameroon.

Nevertheless, in France for a very small sample of Muslim teachers, and in Lebanon with a more significant sampling of the diversity of religions, there are some differences between Muslim and Christian teachers, Muslim teachers being more creationist, while they are sometimes more evolutionist than their Christian colleagues in Burkina Faso. The analysis of our results in Lebanon is particularly interesting, showing that there is no significant different between the answers of Druze (a category of Muslim) teachers and Christian teachers, as well as between Shiites and Orthodox teachers.

In the three countries of Maghreb (Morocco, Algeria, Tunisia), almost all the interviewed teachers are Muslim (Sunni), and this kind of comparison is therefore impossible.

To go further in the analysis of our data, we can focus our attention on all the Muslim teachers of our sampling (table 1) to identify the controlled parameters correlated with their answers.

\section{-III- Are the Muslim teachers' conceptions related to controlled parameters?}

This paragraph deals with the 2130 Muslim teachers in the whole sample (table 1).

From our data, today related to 28 countries, there are Muslim teachers in only 12 countries (table 1), and we group those from Denmark (9), Sweden (3) and Estonia (1) in the category "Scandinavia" (13 teachers). 
We did first a Principal Component Analysis (PCA: Appendix A9) showing that the conceptions of Muslim teachers are structured by the two first principal components, which combine two oppositions: The first opposition differentiates between the most creationist conceptions versus the less creationist ones (questions B28, A64, B48, A62, B29b). The second opposition differentiates between answers with more knowledge versus those with less knowledge of certain processes of evolution (questions B46, B45, B47 and B44). Independently of being more or less creationist versus evolutionist, the interviewed teachers varied in their knowledge of the relative importance of transposons, viruses, environment or intelligent design in species evolution: this shows some absence of interaction KV between knowledge and values. Nevertheless, the answers related to the importance of natural selection (B43) and chance (B42) are more correlated with the most evolutionist answers, showing here some interaction $\mathrm{KV}$.

Between-class analysis differentiating the countries of the Muslim teachers. The two first axes intervene in accounting for the differences between the countries (Appendix A10). French Muslim teachers, and also, even if a little less, Muslim teachers in Burkina Faso and in Scandinavian countries, are more evolutionist than their Muslim colleagues of the other countries, have more knowledge on the processes of evolution, and associate more the origin of humankind to evolutionist expressions. The figure 4 presents the Muslim teachers' answers (grouped by country) to the questions A62, B28 and B7. It is interesting to notice that Sub-Saharan Muslim teachers are less creationist than their colleagues of the three North Africa countries. They also more willing to accept inclusion of Chimpanzees in the genus Homo, while the French Muslim teachers are more reticent for that, as are the teachers of their countries of origin (mainly Algeria, Morocco, Tunisia).

When looking at the figure 4, we have to keep in mind that there are few Muslim teachers in the European countries. Nevertheless, in each country, there is the same proportion of the six sub-samples as in other countries, with only a little more biology teachers in the Gabonese sample, and fewer biology teachers in the "Scandinavian" sample. 


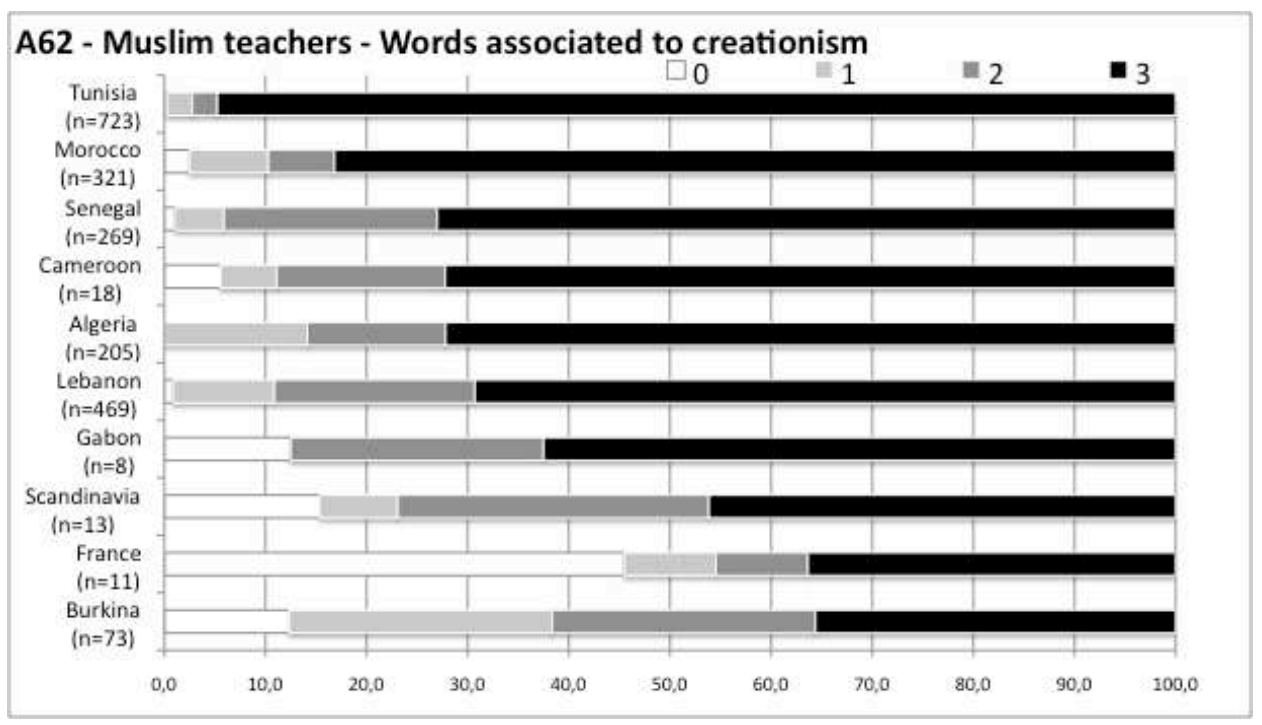

\section{B28 - Muslim teachers - Origin of humankind}

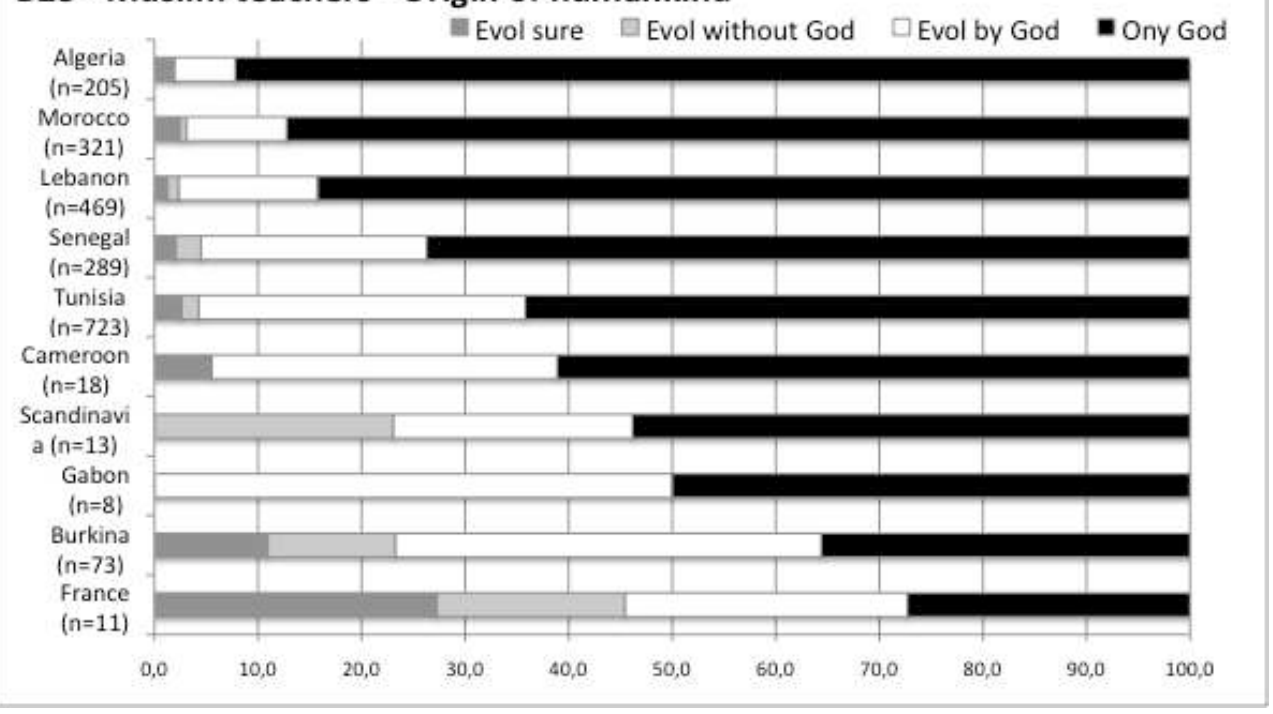

B7 - Muslim teachers - Chimpanzee in genus Homo

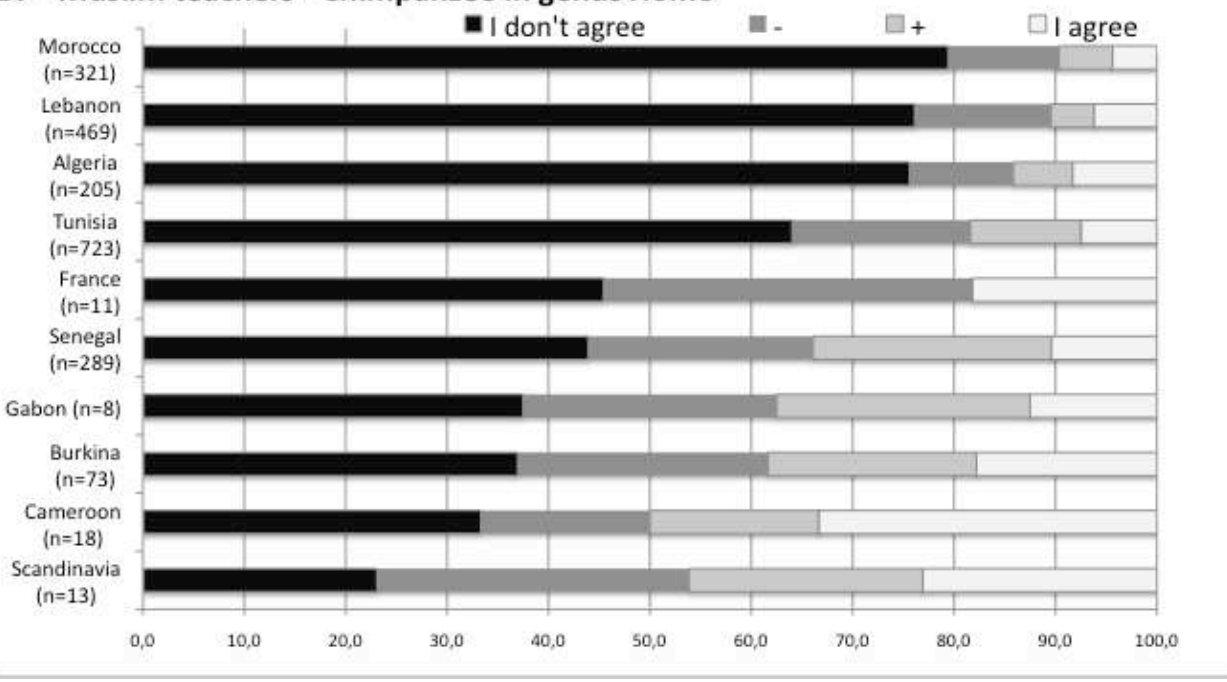


Figure 4. Muslim teachers ( $\mathbf{N}=\mathbf{2}$ 130): Teachers' answers (grouped by country) to the questions:

- A62 (number of expressions associated to the origin of humankind): black= 3 creationist expressions, dark grey $=2$, grey $=1$, white $=0$.

- $\quad$ B28 (the origin of humankind): in grey, evolutionist answers; in white: evolutionist and creationist answers; in black: creationist answers.

- B7 (inclusion of Chimpanzee in the genus Homo): from I don't agree (white) to I agree (black).

The main conclusion of this between-class analysis is the heterogeneity of Muslim teachers' conceptions of evolution, depending the country where they are living. There is not an international standard of creationist beliefs linked to the Muslim religion. For instance, $65 \%$ of the Muslim teachers in Burkina Faso ticked the evolutionist or the evolutionist + creationist items when answering to the question B28 versus only $8 \%$ in Algeria (Figure 4-B28).

The Muslim teachers' conceptions of evolution are very different depending their country. Are there other controlled parameters differentiating their conceptions of evolution?

\section{Between-class analysis differentiating biologist from non-biologist Muslim} teachers. We call "biologist teachers" the pre-service and in-service biology teachers of secondary schools, but also the pre-service and in-service primary school teachers with University degrees in biology.

The between-class analysis shows a significant difference between biologist and non-biologist Muslim teachers, but limited to some questions related to their knowledge of the importance of some processes of evolution: mainly natural selection (B43) and transposons (B46). There is no significant difference for the questions related to creationism, showing here an absence of interaction between knowledge and values.

Between-class analysis differentiating the age of Muslim teachers. There is no significant difference among the categories of ages.

\section{Between-class analysis differentiating the level of University training of}

Muslim teachers. The difference is significant but can be a consequence of unequal repartition of the teachers' level of training among countries. When we suppress the effect of country (by PCAOIV), the new analysis shows no more significant difference; while, when suppressing the effect of the teachers' level of training, the country effect is still clearly significant. That means that the initially observed effect of the teachers' level of training is only a consequence of the country effect.

Between-class analysis differentiating the six samples of Muslim teachers (pre-service or in-service, primary or secondary schools, teaching biology or language). Without surprise, the difference among the six groups of sampling is clearly significant, in coherence with the difference between biologist and non-biologist teachers. Teachers of biology (PreB \& InB) know better the importance of different processes of evolution (such as natural selection: B43) and are a little more evolutionist than their other colleagues (e.g. for the origin of life, A64), illustrating here an interaction between more knowledge and less creationist values (Appendix A11).

A gender effect. Female teachers are, in most of the countries, more numerous than male in primary schools and for teaching language in secondary schools (see Appendix A12). In 
consequence, the observed significant gender effect could be a single consequence of this unequal gender repartition.

Nevertheless, it is not. After suppressing (by PCAOIV) all the significant effects described in the precedent paragraphs (country effect, differences between biologists and other teachers, differences among the six samples), the randomization test shows a difference between male and female teachers that is still clearly significant (Appendix A13).

On one hand females have a better knowledge than their male colleagues on the importance of several processes of species evolution: surrounding environment (B45), transposons (B46), viruses (B47), chance (B42), natural selection (B43): for each of these variables, the Chi2 is significant (from $\mathrm{p}=0.001$ to $\mathrm{p}=0.01$ ). On the other hand, females are more in agreement that the emergence of Homo sapiens was the aim of the evolution (A44, p $<0.001$ ) and they are a little more creationist than their male colleagues $(B 28, p=0.0017 ; A 64, p=0.039)$.

Correlation with political and religious opinions (Co-Inertia Analysis). The CoInertia Analysis between the answers to the 15 variables related to evolution, and the answers to the 13 variables expressing the teachers' political or religious opinions (Appendix A14) shows a clear significant correlation between:

(1) The most creationist opinions related to the origin of humankind (B28, A64, B48, A62, B20a, B29b), the disagreement to include the Chimpanzee in the genus Homo (B7), the absence of importance of natural selection (B43) and of chance (B42) in the species evolution;

(2) The highest degree of belief in God (P12a) and the practice religion (P12b) and a political disagreement to the separation between science and religion (A37), or between politics and religion (A37).

The inverse opinions (e.g. the most evolutionist conceptions, and the lowest degree of belief in God) are also correlated. In conclusion, there are two opposing systems of conceptions.

\section{Discussion and conclusions}

\section{Are Muslim countries more creationist than other countries?}

Our main questions of research were to identify if Muslim countries are more creationist than other countries, and if Muslim teachers are more creationist than their non-Muslim colleagues. The international surveys published by Miller et al. (2006) and by Hameed (2008) suggested a positive answer to these questions. Our results show that it is more complex than expected.

The four countries of our sample where $>90 \%$ of teachers are Muslim correspond to the most creationist teachers' conceptions, but it is the same in Lebanon where one third of interviewed teachers are Christian and, in each of these five countries, from 6\% (Algeria) to $31 \%$ (Tunisia) of Muslim teachers are both evolutionist and creationist (Figure 2).

Moreover, our data show important differences among countries when taking into account only the Muslim teachers. For instance, answering to the question B28 (origin of humankind, Figure 4), only $35 \%$ of Muslim teachers ticked the radical creationist item in Burkina Faso, while $92 \%$ did that in Algeria, and we observed various intermediate percentages in the other countries. In the Sub-Saharan countries, teachers' conceptions are less creationist than in Arabic countries (Maghreb and Lebanon), with the exception of Senegal (a country located near Maghreb and with mainly Muslim people). This difference is not a single consequence of the presence of Christian religion in Sub-Saharan countries because, when it is possible to compare Muslim with Christian teachers inside the same country, there is generally no 
difference (Burkina Faso, Senegal, Cameroon, Gabon) with few exceptions: in Lebanon where some Muslim are more creationist than Christian teachers, and in Burkina Faso where it is the other way round when teachers answered the question A64, Muslim teachers were more evolutionist than their Protestant colleagues.

Globally, all our analyses show two main effects: the country effect and the effect of the degree of belief in God and religious practice (whatever is the religion).

Only in some countries of our sample, there are enough Agnostic/Atheist teachers to compare their conceptions with those of their colleagues believing in God (being Christian or Muslim): in Cameroon, the country effect is strong and there is no observed difference, whereas in the other cases, as shown above for Tunisia and France, Agnostic/Atheist teachers are clearly more evolutionist than their colleagues believing in God.

Moreover, when the comparison between Christian and Muslim teachers' conceptions is possible (part II of our results), there is no difference between them inside the same country, with very few exceptions. Even in Lebanon (Figure 3), where Sunni and Shiite but not Druze teachers differ from Christian teachers, these differences are not important and there was also no significant difference between Shiite and Orthodox teachers' conceptions.

In consequence, it appears that there is not a specific effect of the Muslim religion itself on the teachers' conceptions of evolution, but a more general effect of their degree of belief in God, whatever their religion. This effect is one of the characteristics of the country effect.

This country effect needs to be more deeply investigated, to identify the socio-cultural an economic parameters differentiating the countries and possibly explaining the differences observed for conceptions of evolution. For instance, the difference between the four Arabic countries of our sample (Maghreb + Lebanon) and the Sub-Saharan countries (except Senegal) can be linked to their respective economic levels, but also with their respective history, and with features of the Arabic culture. Inside Maghreb, Tunisian teachers are a little less creationist than their colleagues of Algeria and Morocco. The identity of Algeria, after the war with France and the independence in 1962, is politically anti-Occidental, linked to the more and more exclusive use of Arabic language in schools and administrations and to a growing adhesion to Islam over years. The evolution of Tunisia after independence was different, with the secular regime established by Bourguiba, more peaceful with France and less tolerant with respect to radical Islamism (at least until now).

In summary, the creationist conceptions are more linked to the socio-cultural identity of each country, than to the Muslim or Christian religion. This identity includes the nature and importance of religion, and also the history of the country and its economical level.

\section{Knowledge and Values in Muslim teachers' conceptions of evolution}

Another of our questions of research was to identify if the teachers' knowledge on evolution was linked or not to their values sustaining their creationist conceptions. Here also, the answer is not simple. While knowledge related to the importance of surrounding environment (B45), viruses (B47), transposons (B46) or intelligent design (B44) has generally no link with the more or less creationist versus evolutionist conceptions of the teachers, there is often a correlation between the most evolutionist conceptions of teachers and their knowledge of importance of natural selection (B43) and chance (B42). Pre-service and in-service biology teachers have more knowledge of evolution than their colleagues, and are a little more evolutionist, but the difference between biologist and non-biologist teachers differ mainly by some of the questions related to knowledge, but not with respect to their more or less creationist conceptions. Moreover, the shown gender effect is paradoxical, female Muslim 
teachers having more knowledge than their male colleagues, but being a little more creationist.

This important question of a possible link between more knowledge of evolution processes and more evolutionist conceptions is still open. Our results show only partly this correlation, and they deal only with correlation, not with causality. Working on the conceptual change of Tunisian students, Aroua et al. (2009) pointed several difficulties but showed that an appropriate epistemological/historical approach to evolution can have a positive impact increasing the evolutionist conceptions of students.

Our research helps to understand why this impact is difficult. In another work (Author et al., 2012), we put in evidence two opposite "systems of conceptions" where creationism is often linked to more innatism, sexism, homophobia and also xenophobia, and evolutionism with opposite values. In consequence, trying to change students (or teachers)' creationist conceptions is not easy because they are rooted in social practices and values, linked to outdated scientific knowledge.

For instance in Tunisia, while $98 \%$ of interviewed teachers believe in God, $96 \%$ being Muslim, and $85 \%$ practicing religion, $38 \%$ are evolutionist or both evolutionist and creationist (Question A64), 24\% are not homophobic (Question A41), 62\% are not sexist (Question A38) and 63\% are not racist (Question A35) (Author et al., 2012). In Tunisia, the system of conceptions linked to creationism is more defined by the most fundamentalist pole while a large part of Muslim teachers are less fundamentalist. The gap, here as in other Muslim countries, is less between the Muslim religion and other religions or absence of religion, but is inside the Muslims themselves, with a clear opposition today between the most fundamentalist Islam (Salafists for instance) and moderate Muslims.

\section{Muslim teachers in European countries}

In his project of research comparing the Muslim doctors' conceptions of evolution in several countries, Hameed suspected to find a "harsher rejection of evolution in England and Germany than in Muslim countries" (Chang, 2009).

In our sample, there was no Muslim teacher in England, and only one in Germany. Nevertheless, we had some in other European countries (table 1). These teachers were immigrants since one or two generations. In France, all had French nationality. Our results (Figure 4) show the contrary to that expected by Hameed: these Muslim teachers are the most evolutionist Muslim teachers, much more evolutionist than those interviewed in their country of origin. In France, we already analyzed (Author et al, 2009) conceptions of Muslim students (17-18 years old) coming from immigration $(\mathrm{N}=58)$ at their last year in Secondary School, in a High School in the suburbs of Lyon. One third expressed evolutionist conceptions, one third conceptions both evolutionist and creationist, and one third more radical creationist conceptions. These results are convergent with those exposed above from the 11 Muslim French teachers (Figure 4) and strongly differ from the conceptions of Muslim teachers in their country of origin (Algeria or Morocco: $>90 \%$ radical creationist item, Figure 4 ).

Finally, all our results show a major influence of the socio-cultural national context, in each country, more important than a direct and specific influence of the Muslim religion. Islam is an important parameter of the socio-cultural context of several of the countries analyzed in the present paper, but cannot be separated from economical, political, geographical and historical parameters. The challenge of biology education is not to struggle against the Muslim religion, nor to hope that in a country where $98 \%$ of the teachers believe in God, they would have to 
stop, as Dawkins (2006) proposed. The challenge is to help all teachers and students, including Muslim or Christian ones, to be "evolutionist" or "at the same time evolutionist and creationist" as the famous evolutionist Dobzhansky (1973) admitted to be, and to struggle against all the fundamentalisms of any religion.

\section{Acknowledgements}

I warmly thank Charline Laurent for the data analysis, and all the teams who gathered the data in their respective countries under the responsibility of the following team-leaders: Algeria (Farida Khammar), Burkina Faso (Yvette Béré-Yoda), Cameroon (Lawrence Ntam Nchia), Gabon (Laurence Ndong), Lebanon (Iman Khalil), Morocco (Sabah Selmaoui), Senegal (Mame Seyni Thiaw), Tunisia (Mondher Abrougui). I also thank John Stewart for improving the quality of the English of this text.

\section{Funding}

The European Community funded (2004-2008) the project Biohead-Citizen (Biology, Health and Environmental Education for Better Citizenship: FP6 CIT2-CT-2004-506015) for 18 countries, including Senegal, Morocco, Algeria, Tunisia, Lebanon and France. Consecutive work (the other countries mentioned in the present paper, and all the data analyses) was done without any financial support, except occasional funding by the University of Copenhagen (Denmark), by the University of Karlstadt (Sweden) and by the French Embassy in Gabon.

\section{References}

Author (2004) (2006) (2008) (2010) (2012)

Author et al. (2007) (2008) (2009) (2009) (2012)

Aroua, S. (2006). L'enseignement de l'évolution $d u$ vivant. Débat en classe pour l'enseignement de la théorie de l'évolution du vivant en Tunisie. PhD Thesis, ENS Cachan (France) / ISEFC Tunis (Tunisia)

Aroua, S. (2008). Enseignement de l'évolution et contexte socioculturel, le cas de la Tunisie. In M. Coquidé \& S. Tirard (Eds.), L'évolution du vivant. Un enseignement à risque? (pp.137152). Paris, France : Vuibert, adapt-snes.

Aroua, S., Coquidé, M., \& Abbes, S. (2007). Fragilité du statut scientifique de l'enseignement tunisien de l'évolution au secondaire et à l'université : analyse des contenus enseignés. Revue de la Faculté des sciences de Bizerte, 6, 9-18.

Aroua, S., Coquidé, M., \& Abbes S. (2009). Overcoming the effect of the socio-cultural context: Impact of teaching evolution in Tunisia. Evo Edu Outreach, DOI 10.1007/s12052009-0129-0

Baudouin, C. \& Brosseau, O. (2008). Les créationnismes. Une menace pour la société française? Paris: Syllepse.

BouJaoude S., Asghar A., Wiles J., Jaber L., Sarieddine D., Alters B. (2009) - Biology professors' and teachers' positions regarding biological evolution and evolution education in a middle eastern society. in M.F.Tasar \& G.Cakmakci (eds), Contemporary Science Education Research: International Perspectives (pp. 195-206), Ankara, Turkey: Pegem Akademi

Busca, D., \& Toutain, S. (2009). Analyse factorielle simple en sociologie. Bruxelles, Belgium: De Boeck Université. 
Chang, K. (2009). Creationism, minus a young earth, emerges in the Islamic world. The New York Times (Science), published November 2, 2009

Coquidé M. \& Tirard S. (2008) - L'évolution du vivant : un enseignement à risque ? Paris : Vuibert, adapt-snes.

Dagher, Z., \& BouJaoude, S. (2005). Students' perceptions of the nature of evolutionary theory. Science Education, 89, 378-391.

Dawkins, R. (2006). The God Delusion. N.Y.: Houghton Mifflin Company. (Translated in French by M.-F. Desjeux-Lefort, 2008 - Pour en finir avec Dieu. Paris : Robert Laffont)

Djebbar, A. (2001). Une histoire de la science arabe. Paris, France : Seuil (Points Sciences).

Dobzhansky, T. (1973). Nothing in biology makes sense except in light of evolution. American Biology Teacher, 35, 125-129.

Doledec, S. \& Chessel, D. (1989). Rythmes saisonniers et composantes stationnelles en milieu aquatique, II-Prise en compte et élimination d'effets dans un tableau faunistique. Acta OEcologica, OEcologia Generalis 10, 207-232. Available at: http://pbil.univlyon1.fr/R_old/articles/arti060.pdf.

Dray, S., Chessel, D., \& Thioulouse, J. (2003). Co-inertia analysis and the linking of the ecological data tables. Ecology, 84, 11, 3078-3089.

El Gissr, H. (1887). "Ar risala al hamidiya fi haqiqat al sharia al islamiah » (A Hamedian Essay on the Truthfulness of Islamic Religion and the Truthfulness of Islamic Law). Beirut, Lebanon, $524 \mathrm{p}$.

El-Hani C.N. \& Sepulveda C. (2010) - The relationship between science and religion in the education of protestant biology preservice teachers in a Brazilian university. Cult Stud of Sci Educ., 5:103-125.

Gould, S.J. (1983). Hen's teeth and horse's foes. N.Y.: W.W. Norton \& Company.

Graebsch, A. \& Schiermeier, Q. (2006). Anti-evolutionists raise their profile in Europe. Nature, 444, 406-407,

Hameed, S. (2008). Bracing for Islamic Creationism. Science, 322, 1637-1638.

Haroun, G. (1985). Sibli Sumayyil : une pensée évolutionniste arabe à l'époque d'An-Nahda. Publication de l'Université Libanaise section des études philosophiques et sociales XVI 498p., Beirut, Lebanon.

Hassan, R. (2007). On being religious: patterns of religious commitment in Muslim societies. The Muslim World, 97, 437-478.

Hokayem, H., BouJaoude, S. (2008). College Students' Perceptions of the Theory of Evolution. Journal of Research in Science Teaching, 45, 395 - 419.

Ihaka, R., \& Gentleman, R. (1996). R: A language for data analysis and graphics. Journal of Computational and Graphical Statistics, 5, 299-314.

IAP InterAcademy Panel. (2006). IAP Statement on the Teaching of Evolution. http://www.interacademies.net/Object.File/Master/6/150/Evolution\%20statement.pdf

Iqbal, M. (2009). Darwin's shadow: context and reception in the Muslim World. Islam \& Science, June 22. Quoted from Yassin \& Bastide 2011.

Jones, L.S. \& Reiss, M.J. (eds) (2007) - Teaching about scientific origins. Taking account of Creationism. Bern: Peter Lang. 
Kebaïli, S. (2012). Traiter de l'Evolution Biologique. Analyse comparative des contenus textuels des manuels scolaires tunisiens et des panneaux de la Cité des Sciences à Tunis. In M. Abrougui (Ed.), Science \& Technology Education for Development, Citizenship and Social Justice, Proceedings of IOSTE XV in Hammamet (Tunisia).

Keskas, M. (1994). La théorie de Darwin : Le hasard impossible. Paris : Le Figuier

Lecourt, D. (1992). L'Amérique entre la bible et Darwin. Paris : PUF

Mazhar, I. (1917). «Aslu al anwah », traduction arabe de «l'origine des espèces de Darwin », Ed. Librairie de la renaissance Beyrouth- Bagdad.

Miller, D., Scott, E., \& Okamoto, S. (2006). Public acceptance of evolution. Science, 313, 5788, 765-766.

Moscovici S. (1984), Psychologie sociale. Paris, France: PUF fondamental, new- ed 1998.

Moussa, S. (1925). "Nadharyyat at tatawor wa asl al insan » (The theory of evolution and the origin of humankind). Beirut, Lebanon: Al- Maktaba al'asriyya .

Munoz, F., Bogner, F., Clément, P., \& Carvalho, G.S. (2009). Teachers' conceptions of nature and environment in 16 countries. Journal of Environmental Psychology, 29, 407-413.

Portier P., Veuille M., Willaime J.-P. (2011) - Théorie de l'évolution et religions. Paris : Riveneuve éditions.

Quessada, M.-P. (2008). L'enseignement des origines d'Homo sapiens, hier et aujourd'hui, en France et ailleurs : programmes, manuels scolaires, conceptions des enseignants. $\mathrm{PhD}$ thesis, Université Montpellier 2. http://tel.archives-ouvertes.fr/tel-00353971/fr/

Quessada, M.P., Clément, P., Oerke, B., \& Valente, A. (2008) - Human evolution in science textbooks from twelve different countries. Science Education International, 19, 2, 147-162.

Quessada, M.P., Clément, P., Selmaoui, S., \& Valente, A. (2011). L'enseignement de l'évolution dans les manuels scolaires de huit pays riverains de la Méditerranée. Tréma (IUFM Montpellier, France), (Valeurs, représentations et stéréotypes dans les manuels scolaires de la Méditerranée), 35-36, p.21-34.

Reiss, M. J.(2008) - Should science educators deal with the science/religion issue? Studies in Science Education, 44:2, 157-186.

Romesburg, H. C. (1985). Exploring, confirming, and randomization tests. Computers \& Geosciences, 11, 1, 19-37.

Sabatier, R., Lebreton, J. D., \& Chessel, D. (1989). Principal Component Analysis with Instrumental Variables as a tool for modelling composition data. In R. Coppi \& S. Bolasco (Eds.), Multiway data analysis (pp. 341-352). North-Holland: Elsevier Science Publishers B.V.

Teilhard de Chardin, P. (1957). Le groupe zoologique humain. Structure et directions évolutives. Paris, France: Albin Michel.

Yassin, A., \& Bastide, H. (2011). La théorie de l'évolution et son enseignement dans le monde musulman : le cas de l'Egypte. In P. Portier, M. Veuille \& J.-P. Willaime, Théorie de l'évolution et religions (pp. 213-224). Paris, France : Riveneuve éditions. 